UDC 629.7.054.07

Moldamurat Khuralay, Yergaliyev Dastan, Moldamurat Akmaral, Tulkibay Sherkhan Euroasian National university of L. N. Gumilev, Astana, Kazaxstan

\title{
RADAR REMOTE-SENSING INSTRUMENTS OF THE EARTH
}

Настоящая работа развития отечественной ракетно-космической отрасли является дистанционное зондирование Земли. Учитьвая потенциальные возможности Республики Казахстан, можно отметить, что за последние годы были достигнуты определенные успехи в этом направлении. В Казахстане существует ряд программ, направленных на освоение космической сферы. Строится завод по производству малых космических аппаратов. Это позволит в ближайшем будущем запускать на околоземную орбиту собственные спутники различного назначения. Одним из назначений этих спутников является дистанционное зондирование поверхности Земли.

Основные области применения спутникового дистанционного зондирования - получение информации о состоянии окружающей среды и землепользовании, изучение растительных сообществ, оченка урожая сельскохозяйственных культур, оиенка последствий стихийных бедствий: наводнений, землетрясений, извержений вулканов, лесньх пожаров. Средства дистаниионного зондирования эффективны при изучении загрязнения почвы и водоемов, льдов на суше и на воде, в океанологии. Эти средства позволяют получать сведения о состоянии атмосферы, в том числе в глобальном масштабе

\section{ключевые слова}

дистанционное зондирование Земли, системы автоматического управления, спутниковое дистанционное зондирование, способ фотографирования поверхности Земли, электростатические разряды (ЭсР), дифференциальные интерферометрические методики

\section{Introduction}

Radar remote-sensing instruments of the earth one of the directions of development of domestic space-rocket branch is remote sensing of Earth. Considering potential opportunities of the Republic of Kazakhstan, it is possible to mark that certain success in this direction was in recent years achieved. In Kazakhstan there is a row of the programs directed to mastering of the space sphere. The plant on production of small spacecraft's is built. It will allow to launch into Earth orbit own satellites of different function in the near future. One of assignments of these satellites is remote sensing of the Earth's surface [1].

The main scopes of satellite remote sensing obtaining information on state of environment and land-use, a study of vegetable communities, an assessment of a harvest of crops, an assessment of consequences of natural disasters: floods, earthquakes, eruptions of volcanoes, wildfires. Remote-sensing instruments are effective in case of a study of pollution of the soil and reservoirs, ices on the land and on water, in oceanology. These means allow to receive data on an atmosphere status, including on a global scale [3].

This sounding arrives in the form of images, as a rule, in the digital form, processing is carried on a computer therefore the perspective of remote sensing is tightly connected to digital image processing. The central problem of the modern environmental monitoring is obtaining the objective information about the environment. Such information is given by artificial Earth satellites [2].

Reliability of the information which is contained in satellite images in many respects is defined by quality of the pictures received from Space. In turn quality of the pictures received from space depends on many reasons. Very important point is the method of photography of the Earth's surface. There are two main methods of receiving pictures from space. It is an electron-optical method and a radar method[6].

Each of these methods has the advantages and shortcomings. Of course there is a row of problems which need to be solved. Radar methods don't allow to receive pictures in color. Therefore the question of enhancement of radar methods of sounding in respect of improvement of quality of original pictures of the Earth's surface is very important [4].

In article basic reasons of deterioration and reliability of pictures of the Earth's surface were probed by us. A special role is played at the same time by the processes of electrization of a surface of KA causing electric discharges on the surface of units and cable systems. Electrostatic discharges (ESR) arising owing to gymnastics of KA are sources of electromagnetic interferences (EMP). These EMP influence separate elements and devices and onboard systems in general [5].

Main problems of remote sensing of Earth

The main problem restricting technical characteristics of locators is the low power of the accepted signal. At the same time the power of the accepted signal decreases as the fourth level of range, that is to increase range of action of a locator by 10 times it is necessary to increase transmitter power by 10000 times! Naturally on this way quickly came to limits which weren't simple to be overcome. Already at the very beginning of development the fact that not the power of the accepted signal, and its visibility against the background of receiver noises matters was conscious. Lowering of receiver noises was also restricted to natural noise of elements of the receiver, for example thermal. Danny Deadlock was overcome on the way of complication of methods of processing of the accepted signal and the complication of the form of the applied signals connected to it. Broad application of satellite radar data began in 1991 with start of the ERS-1 satellite (European Space Agency) with the radar onboard. The original purpose of start of this first civil satellite radar was defined quite narrowly and was restricted to the decision of sea tasks (monitoring of an ice situation, icebergs, navigation, currents, oil slicks, etc.). However after passing by the satellite of the first ten full strokes of repetition of an orbit it was clarified that this radar has a high potential and for execution of different tasks on the land[7].

Monitoring of offsets of the land surface by results of differential interferometric processing became one more important practical application of satellite radars. If to consider that the ERS-2 satellite is in an orbit and executes shooting still, it is clear that on the considerable part of the globe there are multipass interferometric chains of pictures from 1991 for 2010 so, for example, many European cities were removed every month since 1995 (and since 1991 - till 5-10 once a year).I.e., are available 100-or now 200-flow chains of radar pictures which in case of sufficient coherence can be processed by all possible differential interferometric techniques, with receiving on an output of cards of offsets of the land surface and deformations of buildings and constructions for the period to 20 years [11].

Differences of radar systems from other types of sounding. Shortcomings and advantages

The main distinctive features of radar satellites of new generation is their spatial resolution (to $1 \mathrm{~m}$ ), a possibility of shooting with different polyarization and the subsequent interferometric processing for receiving high-precision TsMR and detection of adjustments of the land surface with the highest accuracy, independence of shooting of cloudiness. 


\section{Труды Международного симпозиүма «Надежсность и качество», 2017, том 2}

To shortcomings of a radar method to belong receiving the image in the form of a black-andwhite picture [8].

The vast majority of operating systems of remote sensing of Earth - system of optical-electronic observation. However, the leading spacefaring nations plan in the next years to enter into composition of national space groups the satellites equipped with RSA. Radar-tracking systems of observation in comparison with optical means have a row of advantages:

independence of weather conditions and time of day, a combination of broad band of the review at big ranges and high resolution capability,

the multilimitation and flexibility of control of operation of RSA allowing to change quickly situation and the sizes of a zone of the review, resolution capability and data representation forms

high efficiency of data acquisition regardless of weather conditions and lighting,

a possibility of observation of the objects hidden by vegetation and located in a near-surface layer of the earth or in a coastal zone of reservoirs (the buried pipelines, communication lines, electricity transmissions, etc.).

scopes of microwave radio-frequency ranges

\begin{tabular}{|l|l|}
\hline Field of application & Range \\
\hline Air radar-tracking systems & Ka, K, Ku \\
\hline Air space and radar-tracking systems & $\mathrm{X}, \mathrm{C}, \mathrm{L}$ \\
\hline Space radar-tracking systems & $\mathrm{S}, \mathrm{P}$ \\
\hline
\end{tabular}

Table 1
Radar remote sensing of Earth is carried out with lengths of waves from $1 \mathrm{~mm}$ to $1 \mathrm{~m}$ and frequencies from 0,3 to $300 \mathrm{GHz}$ corresponding to them.

For radiolocation use microwave radio-frequency ranges which parameters are specified in Shooting with radar-tracking systems significantly differs from shooting in systems in optical band as it is executed in case of the considerable deviation from a nadir. Forradardatathe coordinate system of a picture looks as follows: an azimuth - the direction, parallel paths, and range - oblique distance from the radar to a surface. Values of angles of shooting change depending on type of the radar and the modes of shooting and can reach from $8^{\circ}$ to 60 - Such geometry of shooting causes a row of geometrical distortions in pictures (a figure 1): distortion of oblique range (non-uniformity of permission of a picture on range), effect of a tuck, resuperimposing and radar shadows.Elimination of these effects is executed in case of orthotransformation of pictures on exact TSMR [9].

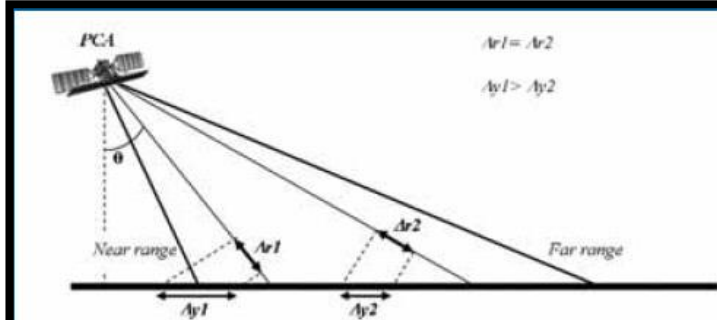

Искажение наклонной дальности

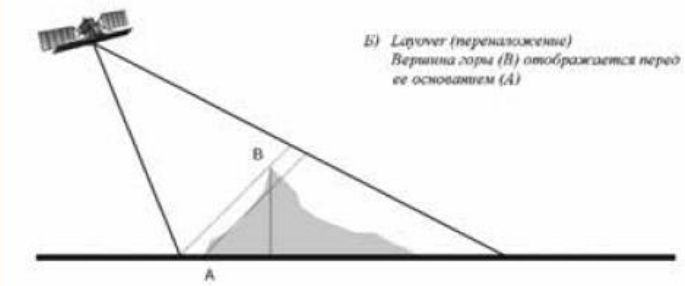

Переналожение

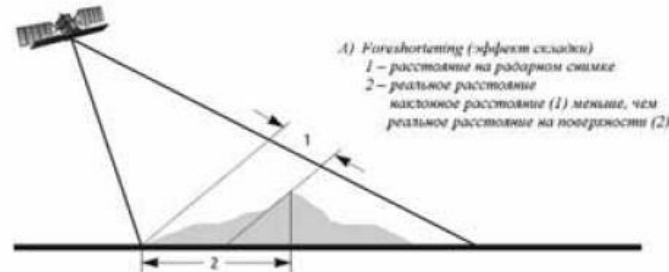

Эффект складки

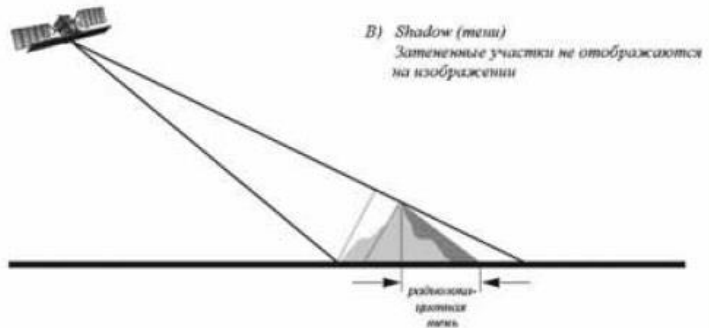

Радиолокачионная тень

Figure 1 - The effects arising in radar pictures caused by geometry of shooting and a land relief
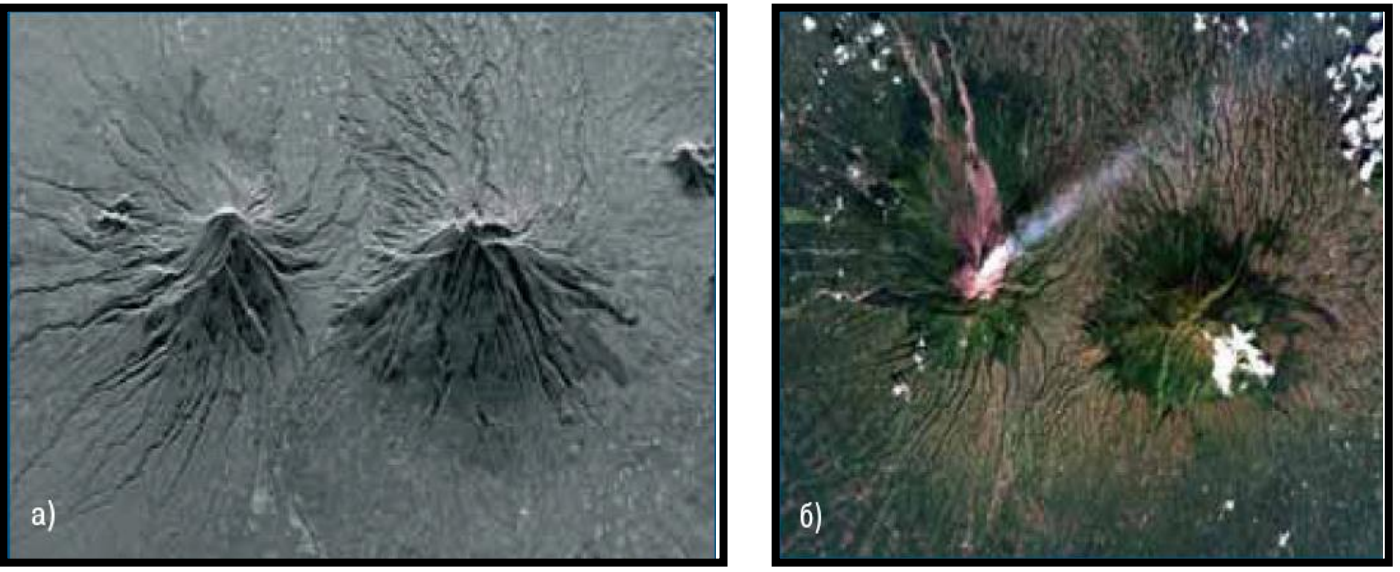

Figure 2 - Comparing of a radar picture and picture in an optical zone of a range: a) TerraSAR-X (the SCANSAR mode, spatial resolution is $16 \mathrm{~m}$ ); b) Landsat-7 (combination of channels: 3-2-1, spatial resolution is $30 \mathrm{~m}$ ). 
Two images which are visually showing the considerable differences in shooting geometry between radar data and data in an optical zone of a range are given in a figure 2 .

Radar images have a row of radiometric features: in pictures even for a uniform surface the considerable variations of the brightness level between adjacent pixels are shown, creating a granular texture. It is a speckle noise which arises because resultant value of specific pixel turns out as a result of addition of the set of the values fixed by system in case of different provisions of the receiving antenna KA, moving on an orbit. In case of image acquisition the principle of RSA is used.

All modern space radar-tracking systems are RSA-systems, and at all radar images there is a speckle noise. Use of RSA-systems is caused by the fact that in case of the small sizes of real antennas of radar-tracking systems it is impossible to get high spatial resolution. When using of the synthesized aperture when the small onboard antenna sequentially creates an antenna grid on rather big section of an orbit, it is possible to reach high spatial resolution. The speckle noise is a multiplicative distortion, i.e., the signal is stronger, the distortion is stronger. For elimination a speckle noise different types of filtering are used. Along with a speckle noise, at the image there are radiometric distortions caused by shooting geometry. As shooting is carried out under different angles for different points of a picture, nonuniformity of brightness across the field of a picture appears: in case of a small angle - is brighter, than in case of a bigger angle of shooting [10].

Conclusion

This distortion is eliminated by introduction of different gain amounts of the antenna across the field of a picture. One more group of distortions is called by geometry of shooting and a relief of a surface: these are areas of shading and resuperimposing, they treat geometrical distortions, but also influence radiometry. Many of the modern radar-tracking DZZ satellite systems (ALOS PALSAR, TerraSAR, Radarsat 2, etc.) allow to receive images in case of different polarization of radiation. Polarization is defined by orientation of a vector of an electromagnetic induction, in case of interaction with an object polarization changes and bears in itself information on an object.

\section{REFERENCE}

1. Kantemirov Yu.I. The review of the modern radar data DZZ and techniques of their processing with use the PC SARscape//Geomatika Log 2010, No. 3, page 42-46.

2. Nikolsky D.B. Comparative review of the modern radar-tracking systems//Geomatika Log 2008, No. 1, page 11-17.

3. Shovengert R.A. Bases of remote sensing of Earth//Book "Remote sensing. Methods and models of image processing" 2007, from 17-19.

4. B.M. Balter, V.V. Egorov. Methods and possibilities of remote sensing. Totals; science and technology; It is gray. Research of space; spaces. M.: VINITI, 1981, t. 16,191s.

5. Physical bases, methods and means of researches of Earth from space (under. edition докт. техн. Ya. L. Ziman's sciences). //Totals of science and technology. It is gray. Earth research from space. M.: VINITI, 1987, t. 1,196s.

6. V.V. Egorov, V.I. Tarnopolsky. Physical bases of remote sensing; Earth from Kocmoca.//Materials of the international educational seminar of the UN on application: remote sensing, Baku, Elm Publishing house, 1977, page 21-37.

7. Ya.L. Ziman. About further development of methods of a research of Earth from KocMoca.//Issled. Lands from space, 1980; No. 1, page 125-133.

8. A.Z. Razyapov, I.V. Kudrin, D.A. Shapovalov, A.M. Stepanov. Monitoring of atmospheric pollution of the urbanized territories (course of lectures), м., МИСиС, 2001, 54 pages.

9. N.A. Armande, A. M. Volkov, A. I. Zakharov, I.S. Neumann; G.M. Chernyavsky, A.V. Shishanov, A.S. Shmalenok. Perspective; domestic; satellite radars with the synthesized aperture://Radio engineering and electronics. 1999, t. 44, No. 4, page 442-447.

10. A.I. Kanashchenkov, L.A. Vedeshin. Space radars; meter range: opportunities, and perspectives to uses in distant zondirovaniizeml; (state-of-the-art review).//Issled. Lands from space, 2004 (in the printing).

11. Novel N., Moldamurat X., Radar methods of sounding of the earth// "Science and education the student and young scientists of 2014 " a name IX of the international scientific conference, page 3210 - 3213, on April 11, 2014 the city. Astana.

12. Шепель В.И., Ергалиев Д.с., Тулегулов А.Д. Сравнительный анализ глобальных навигационных спутниковых систем. Надежность и качество-2012: Международный симпозиум.- Пенза, 2012., том 1. C. $469-471$

13. тулегулов А.Д., Ергалиев д.с., Онгаркызы А., Артыкбаев К.С.The importance of researching the satelittes with the purpose of solving problems. Надежность и качество-2013: Международный симпозиум.- Пенза, 2013., том 1. - С.135-138

\section{UDC 681.3 .8}

Moldamurat Khuralay, Yergaliyev Dastan, Moldamurat Aibek, Moldan Argyn

Euroasian National university of L. N. Gumilev, Astana, Kazaxstan USE OF THE MODERN MICROCONTROLLERS IN RADIO ENGINEERING DEVICES

В этой статье рассматривается применение микроконтроллера, которые используются во всех сферах жсизнедеятельности человека, технических устройствах. Их можно встретить в огромном количестве в промышленности и бытовых приборах: станках, автомобилях, и в радиотелекомуникационных системах и робототехнике. Преимущества данного устроиства в простоте подключения и большие функииональные возможности. С помощью программирования микроконтроллера можно решить многие практические задачи аппаратной техники. Цель данной статьи показать преимущественные характеристики использования современных микроконтроллеров в радиотехнических устройствах

\section{ключевые слова:}

Цифро-аналоговые и аналого-цифровые преобразователи (ЦАП- АЦП), системы автоматического управления, микроконтроллер управление (МКУ), радиотехнические устройства (РТУ), программное обеспечение микроконтроллеров

Introduction

The microcontroller which are used in all spheres of activity of the person, technical devices. They can be met in a huge number of the modern industries and household appliances: machines, cars, and even in the radiotelekomunikatsionnykh systems and robotic technology. Preiumeshchestva of this device in a prostate of connection and great functional capabilities. By 